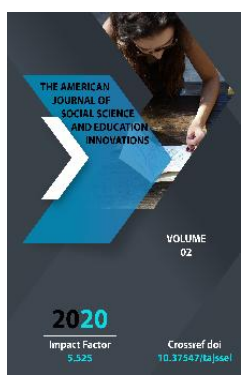

\section{The History Of Construction Of The Mirzachorbog Palace And Problems And Solutions In The Repair Process In The Years Of Independence}

\author{
Jasur Fakhriddinovich Savriev \\ Independent Researcher Of Bukhara State University, Director Of Karmana District Vocational \\ School Of Navoi Region, Uzbekistan
}

Journal Website:

http://usajournalshub.c om/index,php/tajssei

Copyright: Original content from this work may be used under the terms of the creative commons attributes 4.0 licence.

\title{
ABSTRACT
}

During the reign of Karman, the second capital of the Bukhara Emirate, the emir of Bukhara Abdulahad Khan was one of the favorite corners of the emir, which was built during the reign of Karmanada and his son Sayyid Alimkhan, the Palace of Mirzachorbog Amir was studied among the squares with its beauty, amazing architecture, graceful embroidery ganchkor and an architectural structure. Reconstruction of the palace, as well as restoration of dilapidated parts of the building, prevention of the dilapidated state of Mirzachorbog, looting by negligence is one of the most pressing problems today.

\section{KEYWORDS}

Amir's reception, attic, veranda, foundation, madon, bricklayer, surah yard, zarav, pattern, ganchkori, sinch, pencil, gujum.

\section{INTRODUCTION}

Repair and restoration of architectural monuments, their use for modern purposes is one of the most pressing problems in the science and practice of modern restorers. In this regard, without studying the foundations of the historical formation of the repair of architectural monuments, it is difficult to achieve efficiency in solving this complex and urgent issue for our republic. The idea of treating historical buildings as monuments, that is, as objects of cultural heritage, arose during the European Renaissance. However, during this period, the assessment and respect for historical buildings as monuments 
have not yet come into force. As a result, they were underestimated and sometimes even used as building materials.

\section{THE MAIN RESULTS AND FINDINGS}

It is well known that the history of Karman, as well as the palaces and courtyards of the emirs located here, still attract the inhabitants of this land from 7 to 70 years old, like a shining pearl, even if it is in ruins or on the verge of extinction. During the reign of the Karman principality, the second capital of the Bukhara Emirate, many gardens and palaces were built during the reign of the Bukhara Emir Abdullah Khan (born March 26, 1857 in Karman) and his son Sayyid Alimkhan. Among them are Askarbod Charbak, Charmgarchorbog, Dzharchorbog, Bagi

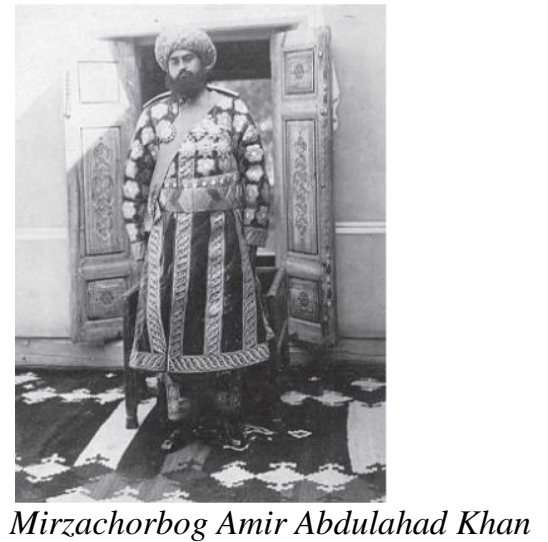

Master Shirin Murodov is known as the master who created his school after 15 years of work on the restoration of Karmani and the surrounding herds and palaces. The palace was built in a complex architectural style using mainly straw and bricks as building materials; the building is divided into two parts. At that time, that is, at the end of the 19th - beginning of the 20th centuries, the garden palaces of the Bukhara Khanate differed from the garden palaces of the Fergana and Khorezm khanates in that they were formed as a separate garden
Olchin, Gulchorbog, Khayrabodchorbog, Khanchorbog, Zakochilar Nasirbodom Charbog and Mirzachorbog, one of Amir's favorite corners. Mirzachorbog stands out among these palaces and courtyards for its beauty, amazing architecture and graceful plaster drawings.

Mirzachorbog Palace was designed by Amir Abdulakhadkhan on the banks of the Zarafshan River, on the eastern side of the modern M-39 Tashkent-Bukhara road of the Great Silk Road in 1900-1905. Karman masters under the leadership of Shirin Murodov built together with Sultan Kori, Najar Torah, master Dost, master Latiflar. The palace project was prepared in accordance with the proposal and instructions of the emir, combining European and Central Asian architecture.

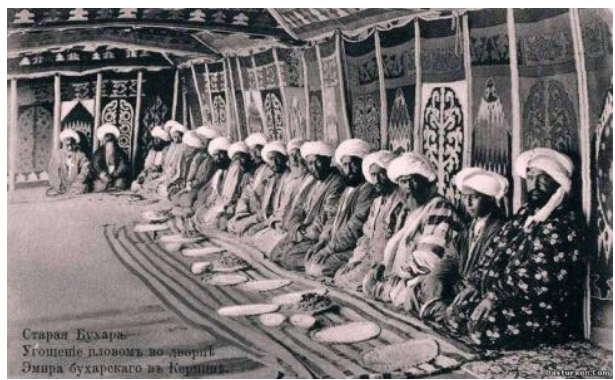

Mirzachorbog Palace: Emir presents pilaf to karmanskiy beys

ensemble on a large air territory outside the cities. The architecture of Bukhara's palaces over the past hundred years reflects the European culture of construction. For example, the architectural monument Shirbudun in the Kagan of Bukhara region, the Sitorai Mokhi Khossa palace and the Mirzachorbog-amir palaces in Karman can be traced in the Central Asian charbagh style, Russian and Moorish Gothic and local artistic elements. 
According to the elders, about 100 craftsmen and laborers were involved in the construction of the palace. The first one is a building $8 \mathrm{~m}$ wide, $18 \mathrm{~m}$ high and $8 \mathrm{~m}$ high. On the instructions of the local weaver Gulam Zaripov, the squirrels were interconnected in the form of a swallow. The shells were cut in

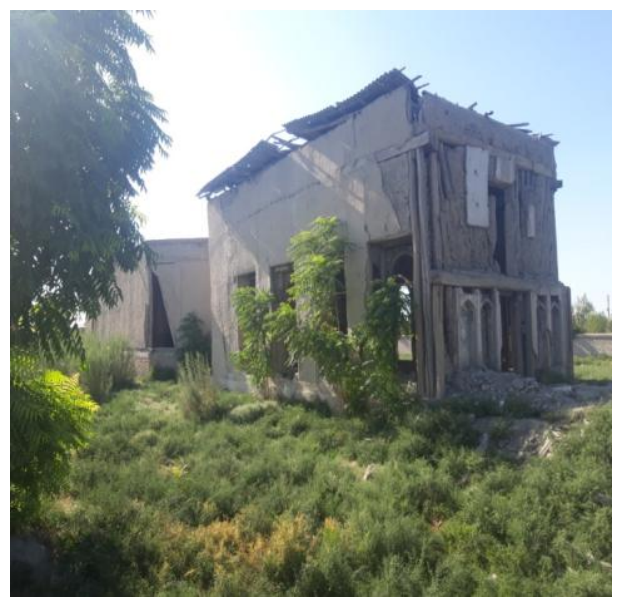

the same plane, and even the history of construction surprised the craftsmen who are now building chisels. The wall thickness is 80 $\mathrm{cm}$, the foundation is $1 \times 35 \mathrm{~cm}, 25$ rows of flat rectangles $20 \times 22$ with a thickness of $4.5 \mathrm{~cm}$ are made of burnt bricks, the 26th row is stacked vertically.

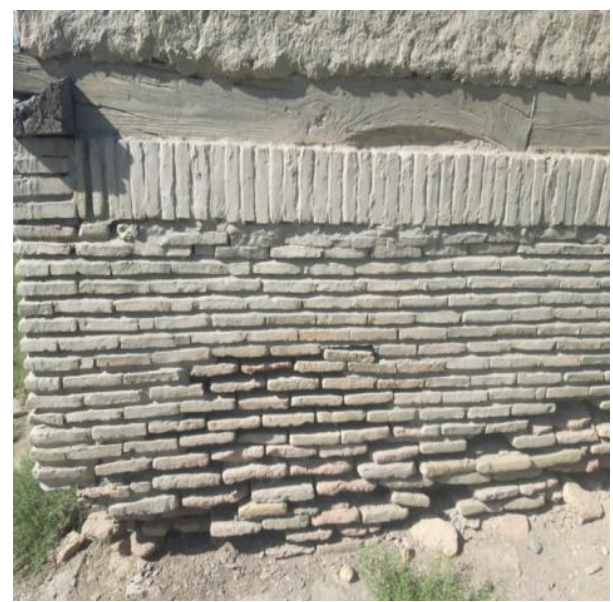

Current view of Mirzachorbok Palace (as of September 4, 2020)
As it turns out, these bricks still differ in that they do not absorb dirt, do not salt and do not crack in the scorching sun, only some areas have turned yellow and become invisible. This Muslim brickwork guarantees the building's earthquake resistance. The ruins of the current palace testify to the skillful use of raw materials used in every construction process. The squirrels can be seen mainly come from the Gujum tree, the saffron sticks at the top of the palace, and the $4 \mathrm{ft}$ squirrel sticks that connect them together. A curtain $30 \mathrm{~cm}$ high was made between the roof beams.A study of the present ruins of Mirzachorbog showed that the raw materials used to make the 80 $\mathrm{cm}$ thick wall, that is, the dirt, was the same as 10 days a week ago, that is, the remains of the wall were hard, even polished wall of cement and silt. and at this level it is poorly preserved. The Amira check-in counter in Mirzachorbog is separate and consists of two rooms, a $6 \mathrm{x} \mathrm{m}$ hall and a hotel hall with 15 rooms $6 \times 12 \mathrm{~m}$ on the west side. 

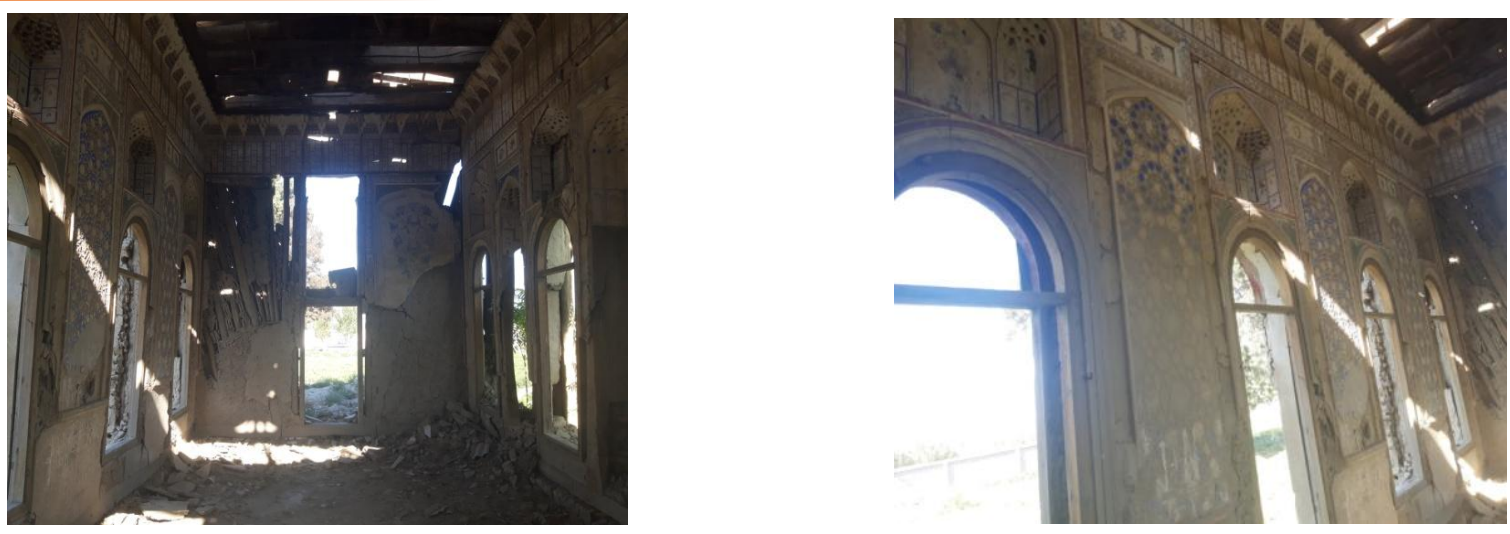

Samples of decorative works on the walls of the Mirzachorbok Palace Hotel, preserved until August 18, 2020.

The height of the hall is $6 \mathrm{~m}$, the height of the corridor is $3 \mathrm{~m}$, the height of the attic above it is $3 \mathrm{~m}$. There are 2 doors in the corridor - the southern and northern fields and one inner door, two windows measuring $1.2 \times 1.5 \mathrm{~m}$ on the east and north sides. In the corridor there are 10 arches, decorated on the basis of drywall, with a total size of $0.8 \times 1.5 \mathrm{~m}$.On the northern and southern sides of the attic there are two windows measuring $1.2 \times 1.5 \mathrm{~m}$.

The colors of the walls in the Amir lobby are painted with natural egg-colored paints, and the ganch carving stands out from the rest of the premises, although more than 100 years have passed.
The artistic significance of the Mirzachorbog Palace lies in the fact that some parts of the building, such as the Amir Palace, were imitated by European methods, that is, some of the windows in the building were large and arched, which were modeled after the palaces of European kings. All this manifests itself in the design of the building, in the decoration of the palace garden, in the construction of awnings and other corridors, in the fact that the palace garden becomes more attractive with fruits and flowers. The fact that the lower parts of the walls of the palace are decorated with glue glaze, and the cornices on the upper parts are skillfully carved from ganch, is a fact associated with the decoration of the rooms of Sitorai Mokhi Khossa in Bukhara. 


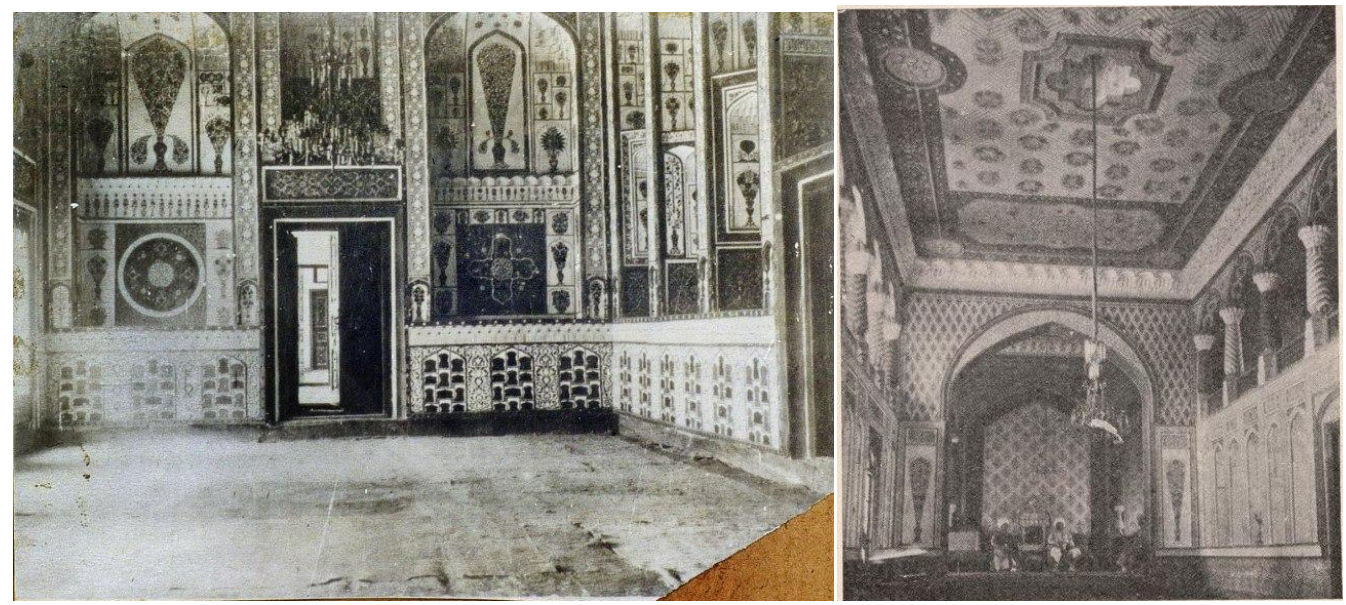

Sitorai Mokhi Khosa Palace in the Bukhara Emirate (view of 1920)

Painting and plaster, which became widely used in the architecture of that period, were widely used in mosques, schools, the homes of the rich, and wooden products discreetly decorated the vaulted ceilings made of plaster. The reception room in the palace is amazing as it is created by the divine power with its unique pattern, variety and charm of each sculptor, and the walls are with special attention to the patterns of leaves, fruits and petals.

Plasterers, woodcarvers and artists from Fergana, Bukhara, Kokand and other cities were invited to decorate the Amir's palace. Makeup and bright colors are very well chosen due to the penetration of light into the room. This must have been taken into account by the masters who worked on the repair. This building was considered the most prominent architectural example of Karman in the early twentieth century. According to local potters, the decoration of the Emir's palace took into account the size of the room, lighting, humidity, etc. It turns out that the hotel, that is, the Amir's lobby, is a summer room, built mainly in the north to keep cool. The walls are made of two rows of shells, and the interior is also filled with flat raw bricks. It was cool in summer and warm in winter, which meant that the air was evenly distributed.

It can be seen that the artist-architects used the following colors when painting carved plaster, when blue, yellow, red and other colors were combined.
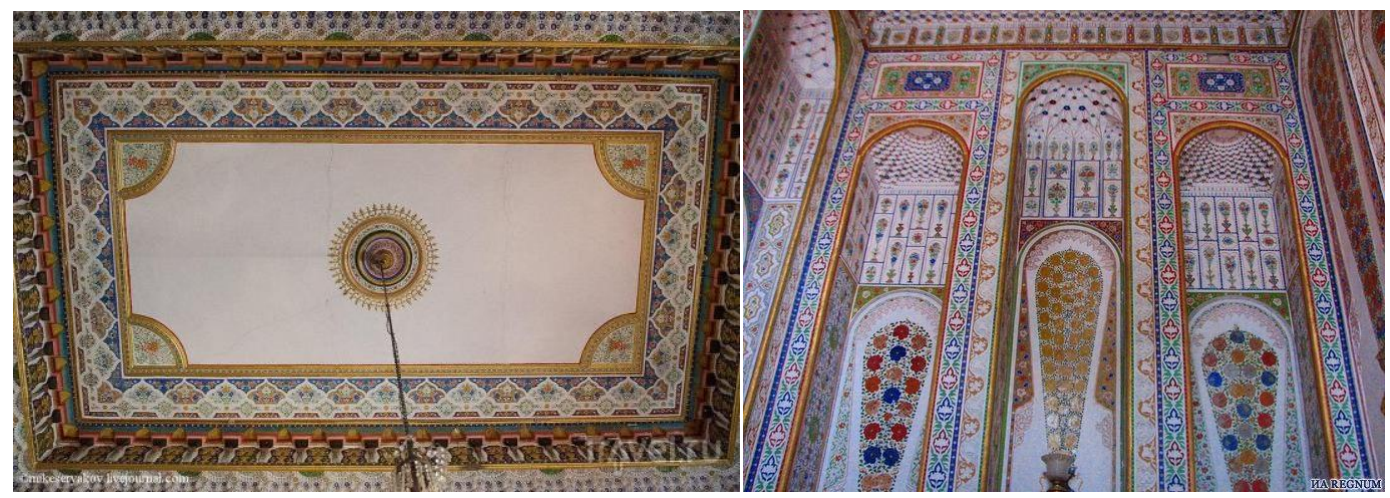

Samples of decorative works of the "Sitorai Mokhi Khosa" palace in the Bukhara Emirate.

(Created by folk master Shirin Murodov) 


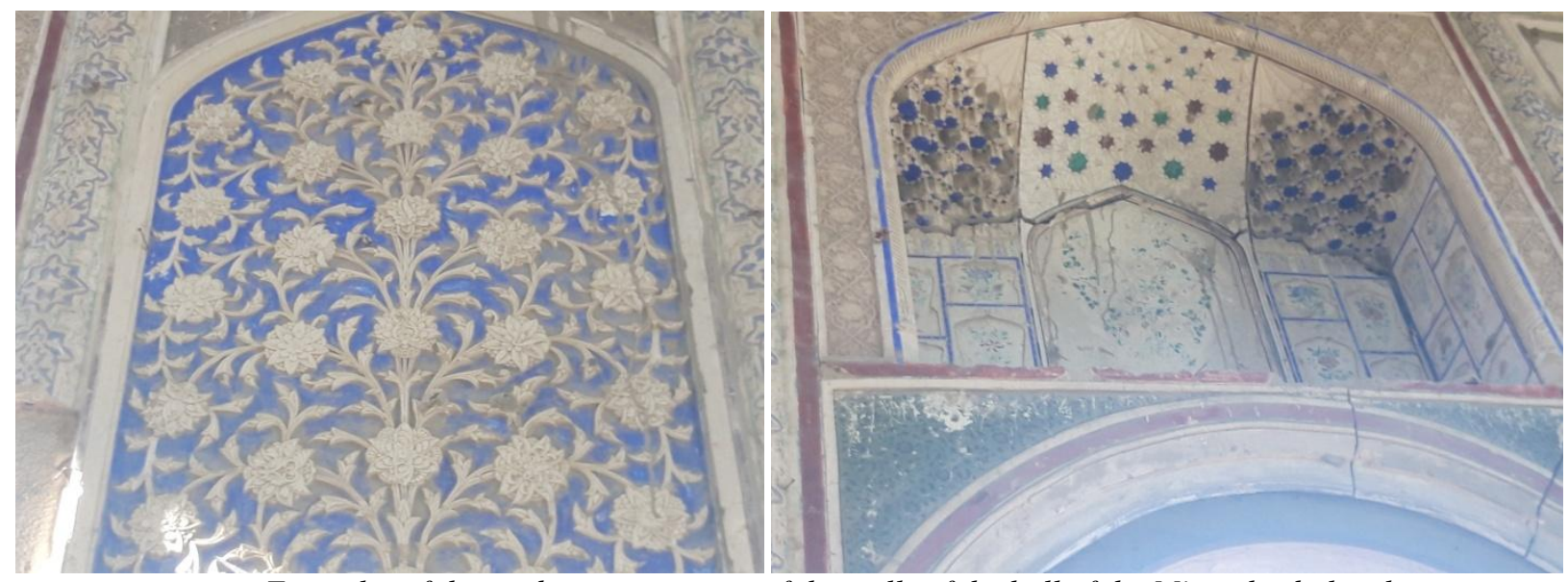

Examples of the modern appearance of the walls of the hall of the Mirzachorbok palace

(Created by folk master Shirin Murodov)

Although the colors for the palace decorations were naturally executed, they have not lost their charm, although 115 years have passed since then. The palace is a 15 -storey building, which is decorated with exquisite taste in the art of wood carving and oriental painting. The entrance to the hotel is through a sunken door through a patterned door measuring $1.5 \times 2.2 \mathrm{~m}$. The doors of the palace, made of precious walnut and cedar, were stolen by local residents. Now only part of the door hinges and part of the frame remain, reminiscent of the 1900s. It was revealed that Amir's reception room was also a waiting room, and as a result of neglect in April 2019, a four-month wooden building collapsed. Currently, only fragments of national patterns remain at the crash site. The strong, sturdy forest was plundered by the locals. Elderly local residents recall that on the threshold, in the hall of the hall, there was a large arched arch with a throne, on either side of which beautiful arches were built, and a throne was erected here. It is known that the throne here was stolen in the temptation of gold.

As if that weren't enough, the place where the throne stood was dug. It still stands as it was excavated. The emir's throne is 4 meters wide and $2 \times 10 \mathrm{mz}$. Remains of the place where the throne was established have been preserved. The entrance to the hotel, to the emir's reception, was through the inner door of the reception. The internal doors were also wooden, and the small circle was painted in a patterned original straw color, which, according to the masters, was one of the rare examples. Above four windows on the north side and four windows on the south side of the hall, the $1 \times 1.2 \mathrm{~m} 2$ arches are expertly crafted in such a way that they add beauty to the room. Carved cups and embroidered ornaments on arches have come down to us today in their original form, casually sprinkled with dust. It should be noted that the eight windows of the building are made in the western (European) style, not in the eastern one. Similar architecture can be seen in the Sitorai Mokhi Khossa Palace, the Emir's summer palace in Bukhara, built in 1913-1914.

On the western side of the emir's palace is the second building (a typical emir's house), which is also a polygonal arrangement of shells and chupkari baubles, in which the invisibility of courtyards (i.e. ulema) is a manifestation of 
masterful architectural art. The building has a very bright geometric (hexagonal) shape in terms of the architecture of the building, it consists of 7 rooms, two of which are trapezoidal. The building's foundation is made of flat bricks $28 \times 28 \mathrm{mz}$ and $24 \times 24 \mathrm{m2}, 4$ meters thick, 1 meter wide, 29 rows. By remeasuring, we see that the height of the foundation is $1 \times 35 \mathrm{~m}$. The bricks are stacked on top of each other, 25 pieces stacked on top of each other, one of them standing vertically, and another apartment on the roof. I think this is a natural phenomenon due to the rise of the earth and the fact that the bricks were left underground. In addition, the structure of the building (i.e. the second building in question) does not occur in any other older buildings.

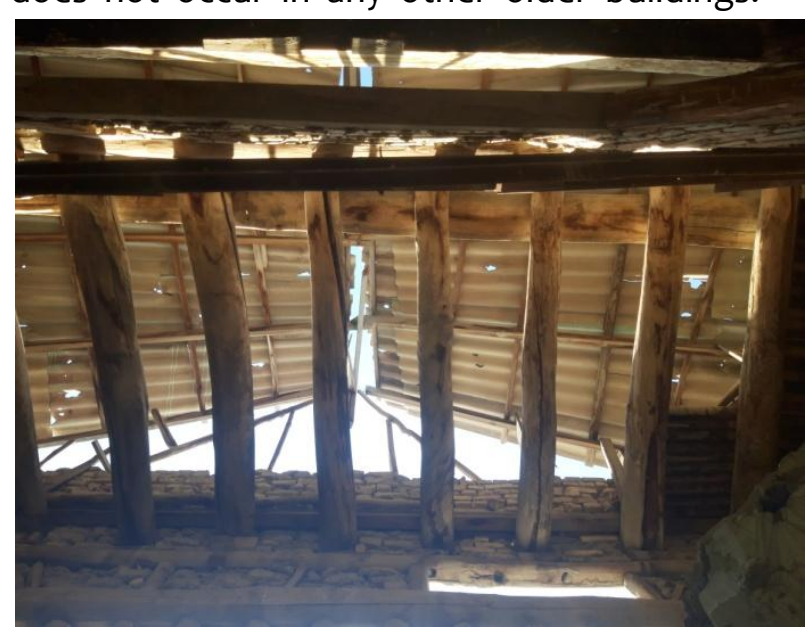

The current dilapidated state of the roof of the Mirzachorbok Palace we can see.

Sinch and zavarava are hexagonal, the prongs are from Gujum wood, the zavaravas are from thick black willow wood, and the polished vases between bolors are skillfully sewn from poplar and willow (i.e. willow and poplar stems are boiled in water to prevent cracking and curling ). Unfortunately, the beams on the roof of the second building of this palace were demolished from 1995 to 2001 - separately. As a result of neglect, the building is in disrepair to this day. The saddest thing is that instead of torn crystal, wooden, thatched and polished vases, the roof of the building was covered with an ordinary broken, slate roof, and the roof of the building was covered with slate,

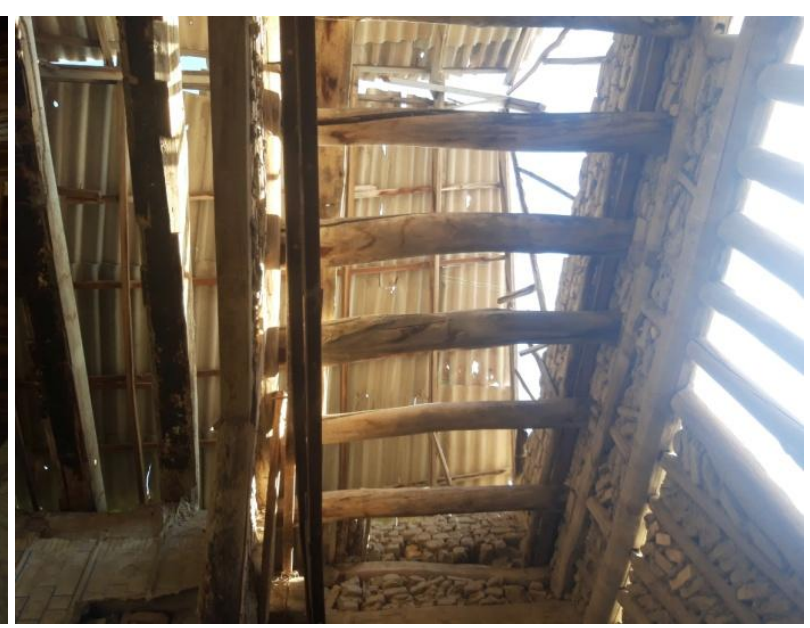

The interiors of the rooms of the building are also designed in a strict oriental style; small fragments of the wall show that flowers grow from large flower pots on the walls and extend to the sky. Large frames on the walls and plaster dome ornaments around the edges of the walls in various places that enhance the mood are beautifully polished with the original straw colors, and more attention is paid to the white color to make the rooms more spacious. True, the drawings, in which ornamental flowers were painted on the wall with natural paints, were embodied in the remains of the wall. At the entrance to the room there is a Madon in the language and description of the masters of Bukhara, consisting of five children. This space serves as a place to take off your shoes, allowing you to move from room to room. This place still exists. At the edge of the platform, on the surface of the courtyard, there was a 12-meterdeep Muslim brick well. The older generation 
confirms that its water is pure and sweet, like spring water. The ruins of this well remained there until 1969, when it was later added and destroyed. Around the courtyard, a garden of various fruit and ornamental trees was laid out. When choosing a site for this property, the following factors may be taken into account:

1) Near the river Zarafshan, the water is gushing, the air is cool.

2) Fertility of the soil to create a garden

3) Cool breeze blowing from the Nurata mountain ranges.

4) Amir Abdullah Khan's interest in hunting is high, and the chosen place is convenient for hunting.

Probably for this reason this place was named Mirzachorbog. Only 6 trees from the beautiful garden at Mirzachorbog, each 3×50m and $3 \times 90 m$ high, compete with the sky, and the building is framed by maples that bear witness to the good and bad days.

The negative impact of the ideological approach on all aspects of public life, including cultural heritage, was more pronounced than the positive achievements achieved during the dictatorial regime of Mirzachorbog. Thousands of historical monuments were destroyed by revolutionary changes, and most of the rest were desecrated. The cultural heritage was not taken into account, and their use for economic purposes became popular. For many years it was used as a warehouse for agricultural work. In 1942-1943, Polish soldiers were allowed to use it as a barracks for military training. In 1974-1975, the regional branch of the mulberry silkworm of the Karmaninsky district was located here. Many mosques and madrasahs were closed. Some of them were turned into barns and, unfortunately, turned into ruins. This tragedy was observed not only in Uzbekistan, but also in other historical cities of the former Soviet Union. Today Mirzachorbog is in disrepair, looted by negligence. if not renovated in a year or two, the place will most likely remain a hill.

In accordance with the Decree of the President of the Republic of Uzbekistan No. PF-3371 dated December 25, 2003 on the creation of the Karmaninsky district in the city of Navoi, Navoi region, together with the Ministry of Culture of the Republic of Uzbekistan with the involvement of sponsors and budget funds. repair assignments were given. Since then, for some reason, these works have been postponed, and finally, in January 2019, the Main Department for the Protection and Use of Cultural Heritage of the Ministry of Culture allocated 3.4 billion soums for the renovation of Mirza Chorbog's palace. Its repair and restoration will be carried out by the private enterprise "Sardoba Malikrabot", which is engaged in the repair and restoration of special historical and cultural objects of the Navoi region.

The correspondent of the mahalla newspaper Tolkien Shernaev wrote on April 12, 2020: "When will the sculpting of historical monuments in Uzbekistan take place?" "Many buildings and structures that bear witness to history over the centuries are on the verge of disappearing from the face of the earth as a result of wars, fires and destruction. Now we can only guess what they looked like and what they contained. But now modern technologies make it possible not only to prevent the complete disappearance of any structure from history, but also to preserve its present appearance. We are talking about the capabilities of technologies in the field of $3 \mathrm{D}$ 
modeling and scanning, which are improving every year. This digital technology helps to directly identify and restore the original appearance of destroyed ancient monuments and structures, from the exterior and interior to the smallest detail. The important thing is that you can watch it as if it were alive, through a 3D model, without visiting a historical monument or building. " Of course, this is also a systemic shortcoming of the Department of Reconstruction and Restoration of the State Inspectorate for the Protection and Use of Cultural Heritage of the Navoi Region, which has developed a specific action plan to solve this problem this year under the Ministry of Culture "Specialized restoration" - Special masters for the repair of historical monuments and buildings were sent to the Research Center for Reconstruction in the directions. In particular, in order to preserve the historical and archaeological monuments in need of restoration and repair in the Navoi region, together with the khokims of the districts, makhalla activists on a voluntary basis began to reconstruct each object, attracting experienced people interested in history as public inspectors. was sent. According to Sh. Kobilov, a specialist of the Interregional State Inspection for the Protection and Use of Cultural Heritage in Navoi Oblast, this year Uzbekistan "On the Protection and Use of Cultural Heritage Sites" A critical analysis of the laws of the republic will be carried out, and a single bill on direct cultural heritage.

Until the end of 2020, scientists and specialists of the republic will be involved in the rehistorical and cultural research of all material and cultural heritage and real estate in the Navoi region. To achieve international recognition of the ancient and rich cultural heritage of Uzbekistan, it is planned to include the Great Silk Road "Silk Road: the oasis of the Zarafshan River" and "rock paintings of Sarmishsay" in the UNESCO World Heritage List. Work is underway to create a model.

In accordance with the instructions given by the President during his visit to the Navoi region on March 12-13, 2019 and paragraph 107 of the minutes of the extended meeting No. 11, "Kasym-Sheikh", "Mirsaid Bakhrom", "Mirzachorbog", located on the Zarafshan Karakum section of the Great silk road. -the world palace ", " Raboti-Malik ", "Sardoba ”,“ Mavlono Arif Deggaroniy "are included in the UNESCO World Heritage List. On May 20, 2019, the Regional Department for Tourism Development and the Central Asian Institute for International Studies (IICAI) signed a bilateral agreement on the inclusion of the above sites in the UNESCO World Heritage List for a total of $1,100.0$ million soums. It was noted that the objects of cultural heritage "Kassym-Sheikh", "Mirsaid Bakhrom", "Palace Mirzachorbog-Amir", "Raboti-Malik", "Sardoba", "Mavlono Arif Deggaroni" in the Lower Zarafshan oasis on the Great Silk Road are included in UNESCO World Heritage List. Work on the inclusion in the list of cultural heritage sites will be completed in April 2021.

\section{CONCLUSION}

On November 11, 2020, a special letter was sent to the Minister of Culture of the Republic of Uzbekistan Nazarbekov O.A. with the aim of repairing the summer residence of the Mirzachorbog-Amir palace in the Old Kurgan makhalla of the Karmaninsky district and preserving the tourist site. On November 16, 2020, Ruslan Saburov posted on the website of the Ministry of Culture on the KUN.UZ telegram channel a critical article entitled "The 
residence of Amir Said Abdulakhadkhan in Karman is being destroyed." both are in good condition. In this regard, we would like to inform you that the settlement is included in the program "Repair and restoration of cultural heritage sites" in 2020. At present, design estimates for the monument have been developed, approved by paragraph 5 of the minutes of the meeting No. 01-02-FJ / 757 dated November 4, 2020 and transferred to the engineering company under the Ministry of Culture of the Republic of Uzbekistan. According to the program for the repair and restoration of cultural heritage sites, the engineering company will allocate 1 billion soums for the reconstruction of the roof of the building, full restoration of the damaged part in the traditional way, and repair of drainage ditches and protective corridors around the building. ... Until recently, we associated the destruction of our historical and architectural monuments, shrines and unique artifacts with the ideology of the dictatorial regime, but our indifference and indifference to the rich heritage of generations is one of the main reasons for this. As in any field, the restoration of architectural monuments requires a very large historical foundation. Thus, the Palace of Emir Mirzacharbog is an invaluable historical monument of Karman, and in order to prolong its natural life and leave it as a legacy to future generations, it is necessary to focus on the construction project, taking into account most of the work, that is, natural and man-made disasters. it is advisable to carry out repairs.

\section{REFERENCES}

1. Podyaplsky S.S., Busonov G.B., Belyaev L.A., Postnikova T.M. Restoration of monumental architecture. $M$. Stroyizdat, 1988.

2. Akhtam Hotamov, Nurkhon Bekniyozov. Karmana Gadimiy Dier - T., NMIU "Uzbekistan" 2007, 194-p. Tashkent

3. Malikov U.E. The architecture of the palaces of historical figures of Uzbekistan. Architectural and construction problems. 2019 №2 last 29-30 pages. URC: 72032 (575)

4. Khotamov A., Khalilov Sh. Echo years T. Adolat 1995, p.23

5. A short guide to Bukhara. Second edition, revised and revised. State Publishing House of the Uzbek SSR Tashkent - 1959.57 pp.

6. The crumbling palace or throne of the emir, carried away by the temptation of gold, and the plundered historical heritage. Shamsuddinhon Bobokhonov publishing house. (https: / hidoyat.uz/)

7. KhotamovA., Bekniyozov N. Karmana Ancient land. Tashkent - "Uzbekistan" - 2007. p.22.

8. The emir's residence threatens with humiliation. The word of the people. January 18, 2018 By Temur Eshboyev

9. Sattarov U. Navoi region.-T.: "Yangi asr avlodi" yfikh'nb, 2004-6 p.

10. LLex / en .. comment. Resolution of the Cabinet of Ministers of the Republic of Uzbekistan dated June 22, 1999 No. 308 "On measures to create the Karmaninsky district within the city of Navoi and the construction of a new center of the Navoi district." 
11. Information on sponsorship events of the Navoi region administration in all directions in January-September 2019

12. 12.When will the modeling of historical monuments of Uzbekistan take place? Mahalla newspaper 12.04.2020 T. Shernaev

13. https:

www.gazeta.uz/uz/2019/06/12/madani $y$-meros/

14. Clause 107 of the instruction given by the President of the Republic of Uzbekistan during his visit to Navoi region on March 12-13, 2019 and the minutes of the extended meeting No.

11.

15. Ministry of Culture: Help from the press service 13:17 / 16.11.

16. Khudoyberdiyevich, D. A., \& Rakhmonqulovich, K. N. (2019). The historical significance of" dastur ulmuluk"("guide to the kings") by khoja samandar termizi. Journal of Critical Reviews, 7(6), 2020.

17. Omonov, Q., \& Karimov, N. (2020). Importance of Ancestoral Heritage. The American Journal of Social Science and Education Innovations, 2(09), 196202. 